\title{
The Design of Learning Methods for Reading Comprehension
}

\author{
Zulia Karini \\ Informatic Study Program, University of AMIKOM Purwokerto, Indonesia \\ zulia@amikompurwokerto.ac.id
}

\begin{abstract}
Keywords:

Reading,

Text,

Learning Method.

The ability to read, in this case is the ability to understand Englishlanguage texts (reading comprehension), is one of the skills that must be possessed by students in a college. This relates to their academic activities that require them to struggle to find sources to support lecture activities. The number of reference sources is present in the form of articles, books, journals and proceedings which are often written in English. Interviews were conducted with several students of University of AMIKOM Purwokerto, Department of Informatics, finding out how to overcome the problem, and trying to provide alternative improvements. To overcome the difficulties experienced by students in reading English texts are by discussing a method of learning reading comprehension. This research is a descriptive study, which describes the facts of difficulties experienced by students in the difficulty of understanding the English text. The instrument used in data collection was a matter of English text. In this study, data analysis used consisted of three steps, namely data reduction, data presentation, and completing conclusions or verification.
\end{abstract}

Article History:

Received: 26-10-2019

Revised : 27-12-2019

Accepted: 29-12-2019

Online : $30-12-2019$

\author{
This is an open access article under the CC-BY-SA license \\ Crossref \\ https://doi.org/10.31764/ijeca.v2i3.2112
}

\section{A. INTRODUCTION}

English is one of the subjects taught from elementary school to college. This is because English is a foreign language that must be learned. In practice both teachers and students still face many problems during the learning process. Problems in learning English are not only found at the level of primary, secondary and upper education, but will continue to the tertiary level. Several studies conducted by Hermayawati (Hermayawati, 2010), Widyawati (Ita Widyawati, 2012), Hasibuan (Viktor Parsaulian Hasibuan, Stevanus Buan, 2013) and Santosa (Santosa, 2016) have proven this with each English language skill.

Learning English is very complex because English has four basic abilities namely Listening (listening / listening), Speaking (speaking), Reading (reading) and Writing (writing). It has three additional abilities namely Grammar (grammar), Vocabulary (vocabulary) and Pronunciation (pronunciation). All components are very important and must be studied if you want to master English well. 
The ability to read, in this case is the ability to understand English texts (reading comprehension), is one of the skills that must be possessed by students in a college anywhere. This is because of their academic activities which require them to struggle to find as many sources of reference as possible to support their lectures, whether it's just to increase knowledge or when they want to complete a lecture assignment. The number of reference sources now comes in the form of articles, books, journals and proceedings which are often written in English.

Reading is flexible, meaning that the reader uses various strategies to read efficiently Reading is not just a process of identifying letters, words, and finally sentences that lead to understanding that is built from letter to word to phrase to sentence. Reading comprehension means that the reader uses the background of his existing knowledge (schemata) to make predictions about what will happen next in the text and about how some unknown new information relates to something already known. The goal is assumed to be the understanding of the message (Bojovic, 2010).

Interviews that have been conducted with several students of University of AMIKOM Purwokerto majoring in Informatics Engineering class of 2017 show the difficulties they experienced when they wanted to understand an English text. Some students when asked to read one sentence in an English text they understand all the vocabulary, but do not understand the message conveyed in the sentence. In the activity of reading an English text, it turns out that not only knowledge of the vocabulary is needed but there are several other aspects that determine the success of understanding an English text. Therefore, Informatics Engineering students at University of AMIKOM Purwokerto, who are not actually students studying English, are deemed necessary to learn to read and understand English texts (reading comprehension).

Learning to read here does not mean learning to read for those who cannot read English, but how to learn to read a text that not only reads what is written, but reads what is implied in a text or sentence. In reading skills, Rahmawati (I. F. Rahmawati, 2011) argues that the problem faced for reading text comprehension lies in the lack of knowledge about reading material and ignorance of how to connect ideas between sentences.

Based on the above background, the following problems can be formulated, namely (1) What are the obstacles faced by students of Informatics at University of AMIKOM Purwokerto in understanding English texts? (2) How to design a reading comprehension learning method that can be applied to Informatics Engineering students at University of AMIKOM Purwokerto?

There are several studies on the analysis of student difficulties in reading an English text including: 1) Pratiwi (Pratiwi et al., 2015) raised the title "Ability to Read English Texts". This study aims to determine the reading ability of students by teaching them to read by interpreting and inferring in a normal way of reading, that is by giving or improving words or structures it is difficult to know how to effectively improve students' reading comprehension; to find out the difference among students' reading skills between normal reading and imitating texts that have been read by their lecturers; and to find out how far the reading comprehension of non-English students is by paying full attention to the vocabulary in the reading text to be able to produce clear understanding. 2) Harida (Harida, 2014) raised the research with the title: "Students' Abilities and Difficulties in Understanding English Text (A Study at the IAIN Padangsidimpuan English Program)". This study describes the students' reading skills and the types of reading strategies used. The results of this study reveal the level of understanding of reading English texts of students is still low due to their lack of knowledge about reading strategies. Both studies 
equally analysed the difficulties of students majoring in English in understanding English texts using descriptive qualitative research methods.

Similar to the previous research, the author intends to conduct a similar research but with the object of research of non-English major students namely Informatics Engineering students at University of AMIKOM Purwokerto to find out the obstacles faced by Informatics Engineering students in understanding English texts and finding solutions by designing methods reading comprehension learning that is appropriate for them.

\section{B. METHODS}

The method used in this study was descriptive qualitative research methods. Bogdan and Taylor in Moleong (Moleong, 2017) define qualitative methodology as a research procedure that produces descriptive data in the form of written or oral words from people and observable behavior. The results of this study contain excerpts from data sets that are said, explained, described, classified, analyzed, and interpreted (IDP Wijana, 2011). The researcher emphasizes notes with detailed, complete, and in-depth sentence descriptions that describe the actual situation to support the presentation of the data.

This research is a descriptive study, which describes factually the difficulty of understanding English texts for students of Informatics at University of AMIKOM Purwokerto. Based on available facts. The instrument used in the collection of data was a questionnaire from the Informatics Engineering student at the 2017 University of AMIKOM Purwokerto class and questions related to reading skills.

\section{RESULT AND DISCUSSION}

\section{Students' Reading Problems}

Several factors influence students' ability in understanding English text. The major problem is dealing with vocabulary. It comes when the experiment was done in this research. The students were given two different texts. The first text was about computer and science and the second one was about economics. The texts were followed by some essay questions. Almost all students could answer the questions in the first text but only few students could answer the questions in the second text. It was merely because their field study was computer and science so that they were familiar enough with the vocabulary given in the text, whereas the vocabulary about economics seemed strange for them. They did not have an ability to obtain meaning from the text due to some new vocabulary.

Another problem arise when the third text was given but this time the text was followed by multiple choice questions. Some students (especially those who read quickly) did not always pay enough attention to detail. They might have a good idea of general meaning of the text, but misunderstand particular points. Sometimes, they also got a completely false impression of the meaning of a part of the passage. It was because they overlooked an important small words among others: a conjunction, a negation, a modal verb, word families, intensifiers, punctuation, denotative/connotative meaning, and question-words.

When students tried to comprehend the text, they just knew the meaning of the words but they could not use the information gained to form generalizations, make inferences, and draw conclusions. From the explanation above, it can be concluded that there were two basic problems for students of University of AMIKOM Purwokerto related to reading comprehension namely vocabulary and detail/specific information. Researcher then designed some reading comprehension learning methods to solve the problems. 


\section{Designing Reading Comprehension Learning Methods}

Problems related to vocabulary when reading the passage can be solved using some learning methods as follows:

\section{a. Using Flash Card}

Flash card is a card containing a small amount of information, held up for students to see, as an aid to learning. Teacher can use it before learning activities to read the text is started. It is like a warming-up activities. Teacher prepares one set of cards. One vocabulary related to the text which is going to discuss is written in one card. Teacher provides 10 to 20 vocabulary which the teacher thinks they would be difficult words for the students. At first, teacher shows the students the first card and ask them the meaning of the word written in it. If the students do not know its meaning, teacher will help the students by reading two to three sentences containing that word and let the students guess the meaning based on the previous sentence(s). If the students still cannot guess the meaning, teacher may help students by giving the synonym and/or the antonym of that word. Teacher can also explain and/or describe the word until the students understand the meaning of the word. This activity may take time 10 to 15 minutes. After the students know some difficult words that will appear on the text, they start reading it and try to understand the text. Having had knowledge about some vocabulary they have studied before, it is found that most students can understand easily what the text is about. For further understanding about the vocabulary they study in the classroom, teacher may give homework to them. Students are asked to make their own flash card, but they have to give more information about the word on the other side of the card, not only its meaning, such as its part of speech, its past form and gerund form (if it is a verb), its similar words, and many other information.

\section{b. Using Spider Diagram}

Spider diagram consists of small circles connected with arrows. Teacher uses this method for pre-reading activity. Teacher writes the topic of the text in a whiteboard. For example, the text is about the function of the computer for human life. In the middle of the whiteboard, teacher writes 'the function of computer for human life' and circles it. Then, students are asked to write as many words as possible vocabulary relating to this topic. Each word is circled and it can be developed into another word by arrows which means the words are connected one another. By having list of vocabulary in the beginning the reading activity, students are able to understand the content of the passage. When they find one word from the text, they must be able to give the synonyms and/or the antonym based on the words they make in the spider diagram.

Problems related to detail/specific information when reading the passage can be solved using some learning methods as follows:

\section{a. Knowing About Contextual References}

Contextual references refer to a word, or words, mentioned earlier in the sentence or paragraph. Their function is to take our thoughts back to something that has already been mentioned. Thus they serve as synonyms or substitutes. Students are given exercises to have better understanding about contextual references. A text is provided for students then they have to underline all references the find in the text. They also must be able to explain what the word refers to. For examples: 
1) A computer is a machine with an intricate network of electronic circuits that operate switches or magnetize tiny metal cores.

"That" in this sentence substitutes or refers to the word "circuits".

2) A computer, like any other machine, is used because it does certain jobs better and more efficiently than human.

"It" in this sentence substitutes or refers to the word "computer".

\section{b. Skimming For Specific Information}

It is not always necessary to read every word of a passage. Skimming through a passage involves reading very fast in order to recognize main ideas and supporting details while skipping (not reading) parts that are not relevant to our reading purpose. An exercise like scanning for information about who, what, where, when and why is a good exercise for students so that they will be familiar with the skimming method. Below is the example of this activity:

Mexican conservationists are wondering how to get rid of killer piranhas that were found yesterday in a lake near Puebla.

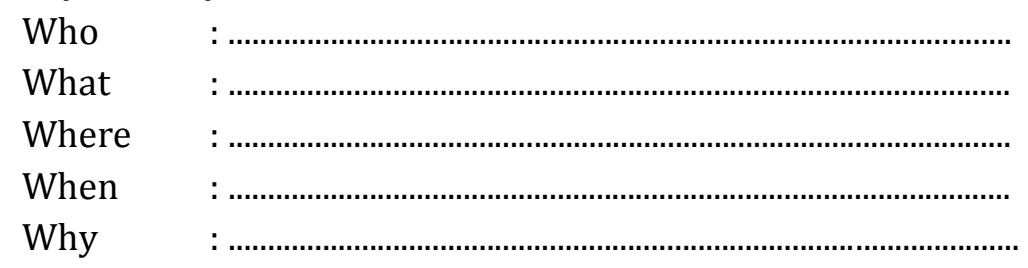

\section{c. How Thoughts Are Related}

This section of readings will concentrate on thought relations within sentences, paragraphs, and longer passages. It is important to be able to recognize and understand signal words or connectives, which introduce, connect, order, and relate individual ideas to larger and often more general concepts, for example: and, also, as well as, besides, finally, furthermore, in addition to, in conclusion, moreover. Students should study these connectives, paying close attention to their function. An exercise can be given to students and they must be able to underline the connectives and determine the function of each connective.

\section{CONCLUSION AND SUGGESTIONS}

The results of this study are to identify the difficulties or problems faced by Amikom University students related to understanding English texts. Found two main problems namely problems related to vocabulary when reading that can be given solutions to teaching methods using flash cards and spider diagrams and problems related to specific details / information. Which can be given solutions to learning methods about contextual reference, skimming and knowledge about conjunctions.

\section{ACKNOWLEDGEMENT}

Thank you to University of AMIKOM Purwokerto which has contributed during the research.

\section{REFERENCES}

Bojovic, M. (2010). Reading Skills and Reading Comprehension in English for Specific Purposes. The International Language Conference on The Importance of Learning Professional Foreign Languages for Communication between Cultures 2010, September 2010, 1-5. 
Harida, E. S. (2014). Students' Ability and Difficulties in Understanding English Text (A Study at English Program IAIN Padangsidimpuan). AL-Ta Lim, 21(3), 183. https://doi.org/10.15548/jt.v21i3.102

Hermayawati. (2010). Analisis Kesulitan Belajar Bahasa Inggris Mahasiswa. Jurnal Sosio-Humaniora, 1(1).

I. F. Rahmawati. (2011). Improving Eighth Graders' Reading Comprehension through Autonomous Strategy. Universitas Negeri Malang.

IDP Wijana, M. R. (2011). Analisis Wacana Pragmatik: Kajian Teori dan Analisis (Y. Kusumawati (ed.); 3rd ed.). Yuma Pustaka.

Ita Widyawati. (2012). Analisis Kesulitan Belajar Siswa Pada Mata Pelajaran Bahasa Inggris Kelas VIII di SMP N 1 Sawahan Madiun Semester Genap Tahun Ajaran 2010-2011. Universitas Negeri Semarang.

Moleong, L. J. (2017). Metodologi Penelitian Kualitatif (Edisi Revisi). In PT. Remaja Rosda Karya (p. 424).

Pratiwi, V. U., Astuti, P. I., \& Handayani, S. (2015). Kemampuan Membaca Teks Bahasa Inggris. Magister Scientiae, O(38), 132-142. https://doi.org/10.33508/MGS.V0I38.789

Santosa, S. (2016). Analisis Faktor Kesulitan Belajar Bahasa Inggris Siswa Tingkat SMA Di Kabupaten Kulon Progo. Universitas Negeri Yogyakarta.

Viktor Parsaulian Hasibuan, Stevanus Buan, E. B. (2013). An Analysis On The Factors Causing English Learning Difficulties. Jurnal Pendidikan Dan Pembelajaran Khatulistiwa, 2(7). 